\title{
Age determination and growth rate of a Callista chione population from the southwestern coast of Portugal
}

\author{
Paula Moura, Miguel B. Gaspar*, Carlos C. Monteiro \\ Instituto Nacional de Recursos Biológicos (INRB, I.P.) / IPIMAR, Avenida 5 de Outubro s/n, 8700-305 Olhão, Portugal
}

\begin{abstract}
The age and growth of the smooth clam Callista chione from the southwestern coast of Portugal were estimated during a $1 \mathrm{yr}$ study period by using both the surface growth rings and internal shell microgrowth lines (by acetate peel method). The von Bertalanffy growth curves obtained by these 2 methods were, respectively: $L_{t}=91.9\left[1-\mathrm{e}^{-0.18(t+0.22)}\right]$ and $L_{t}=98.1\left[1-\mathrm{e}^{-0.15(t+0.43)}\right]$. Based on these, the counting of surface growth rings is appropriate for a quick age estimation of individuals up to $10 \mathrm{yr}$ old $(\sim 75 \mathrm{~mm}$ shell length, SL). For older specimens, analysis of the growth lines in the cross section of shells is recommended, because close to the shell border it becomes difficult to distinguish growth rings on the shell surface. Rapid shell growth occurred in spring and summer, whereas slow growth occurred during autumn and winter, with the deposition of an annual growth ring. The overall growth performance and the phi-prime index were used to compare growth parameters with data from literature about venerid bivalves. These parameters indicated that Callista spp. have a higher growth performance than other venerid bivalves and this is correlated with geographical latitude. The smooth clam achieves sexual maturation at $4 \mathrm{yr}$ of age and reaches the minimum landing size (60 $\mathrm{mm} \mathrm{SL})$ after $5 \mathrm{yr}$.
\end{abstract}

KEY WORDS: Callista chione $\cdot$ Smooth clam - Age $\cdot$ Growth rate $\cdot$ Growth performance · Surface rings $\cdot$ Acetate peel $\cdot$ Portugal

\section{INTRODUCTION}

Knowledge on growth parameters is essential for understanding the biology and productivity of bivalves. Studying vital rates (namely growth) is necessary for modelling population dynamics, which, in turn, is crucial to support exploitation and management (Laudien et al. 2003, Peharda et al. 2007) and to propose effective measures for the protection of the species (Katsanevakis 2007). Growth rates also indicate how much time is required to reach a certain marketable size (Urban 2000), and the relationship between size and age is essential to implement appropriate management strategies (Keller et al. 2002).

Several methods are used to estimate age and growth of bivalves, but there are practical problems with most of them. Size-frequency distribution analysis is a very subjective method, inappropriate for species with a relatively long annual recruitment period and/or highly variable individual growth rates within age groups (Seed 1976, Cerrato 1980). Mark and recapture experiments demand a lot of time to gather data and should only be carried out in areas where fishing activities are prevented (Gaspar et al. 2004a). Analyses of oxygen and carbon isotopic composition are also used for determining the age of bivalves, although the determination of equilibrium or disequilibrium conditions between carbonate and seawater is often difficult, chiefly when large changes in both temperature and seawater isotopic composition take place throughout time (Keller et al. 2002).

The counting of growth rings on the shell surface represents the quickest and most economical method. Although used frequently, this method has several weaknesses (Pannella \& MacClintock 1968, Richardson et al. 1990), e.g. the presence of false rings (Keller 
et al. 2002) and, in older specimens, an eroded umbonal region, or one in which the most recently formed rings are deposited too close together to allow distinction (Richardson 2001). These constraints can be overcome if the acetate peel technique is used to estimate age and growth (Richardson 2001); unfortunately this technique is quite time consuming.

Several studies on the growth rates of bivalves have employed counting the annual growth rings (1) visible on the shell surface or (2) in the microstructure of polished and etched shells. Richardson et al. (1990) studied the growth of Mytilus edulis from offshore production platforms (North and Irish Seas), concluding that only growth rings visible in acetate replicas are a reliable indicator of age. In a study on the growth of Donax trunculus from southern Portugal, Gaspar et al. (1999) observed that the results obtained from both methods provided different estimates of growth rates for the first $2 \mathrm{yr}$. These authors considered that the age can be more accurately determined from shell internal bands (shell cross sections and acetate peel replicas) than directly from external rings. In a study involving venerid species, Gaspar et al. (2004a) estimated age and growth of Chamelea gallina from southern Portugal, concluding that counting of external rings is appropriate for a quick estimate of age, but the use of internal shell growth rings is recommended for the estimation of von Bertalanffy growth parameters. Morsan \& Orensanz (2004) estimated the age and growth of Amiantis purpuratus in Argentina, the shell sections of which showed almost exact correspondence between internal and external bands.

Knowledge on the age and growth of the smooth clam Callista chione (Linnaeus, 1758) is relatively sparse. The first published work on $C$. chione growth was carried out by Hall et al. (1974) using thin sections of shells, but no growth parameters were estimated. Forster (1981) used mark and recapture experiments to estimate growth parameters of a smooth clam population from Whitsand Bay (UK). Keller et al. (2002) obtained information on the growth rates and the settlement time of C. chione from Trieste Gulf (Italy) by analyzing the shell isotopic composition. The external and internal growth rings were used to estimate the growth rates of smooth clam populations from the Aegean and Thracian Seas (Greece) by Metaxatos (2004) and Leontarakis \& Richardson (2005), respectively.

Bivalve fisheries play an important socio-economic role on the southwestern coast of Portugal. In this region, the smooth clam constitutes the target of a specific fishery carried out by the dredge fleet (Gaspar et al. 2001). The purpose of the present study was to estimate the age and growth of a Callista chione population off Arrábida (southwestern Portugal). Two age determination techniques (counting of annual growth rings visible on shell surfaces and those on microstructure of polished and etched shells) were compared to ascertain which method is the most efficient in estimating the age of this species.

\section{MATERIALS AND METHODS}

Samples of Callista chione were collected by commercial dredgers from a site off Arrábida (SW coast of Portugal; 15 to $20 \mathrm{~m} \mathrm{depth;} \mathrm{Fig.} \mathrm{1)} \mathrm{at} \mathrm{approximately}$ monthly intervals between January and December 2004. The shell length (SL, maximum distance along the anterior-posterior axis) of a total of 120 individuals (ranging between 22.76 and $92.56 \mathrm{~mm} \mathrm{SL}$ ) was measured to the nearest $0.01 \mathrm{~mm}$ using a digital caliper.

The valves were examined for the presence of surface annual rings, and the anterior-posterior length of each ring was measured with a digital caliper (Fig. 2A,B). The internal structure of each shell was observed by examining acetate peel replicas of polished and etched radial sections of resin-embedded valves (a detailed description of the method can be found in Lutz [1976] and Richardson [1989]). The depo-

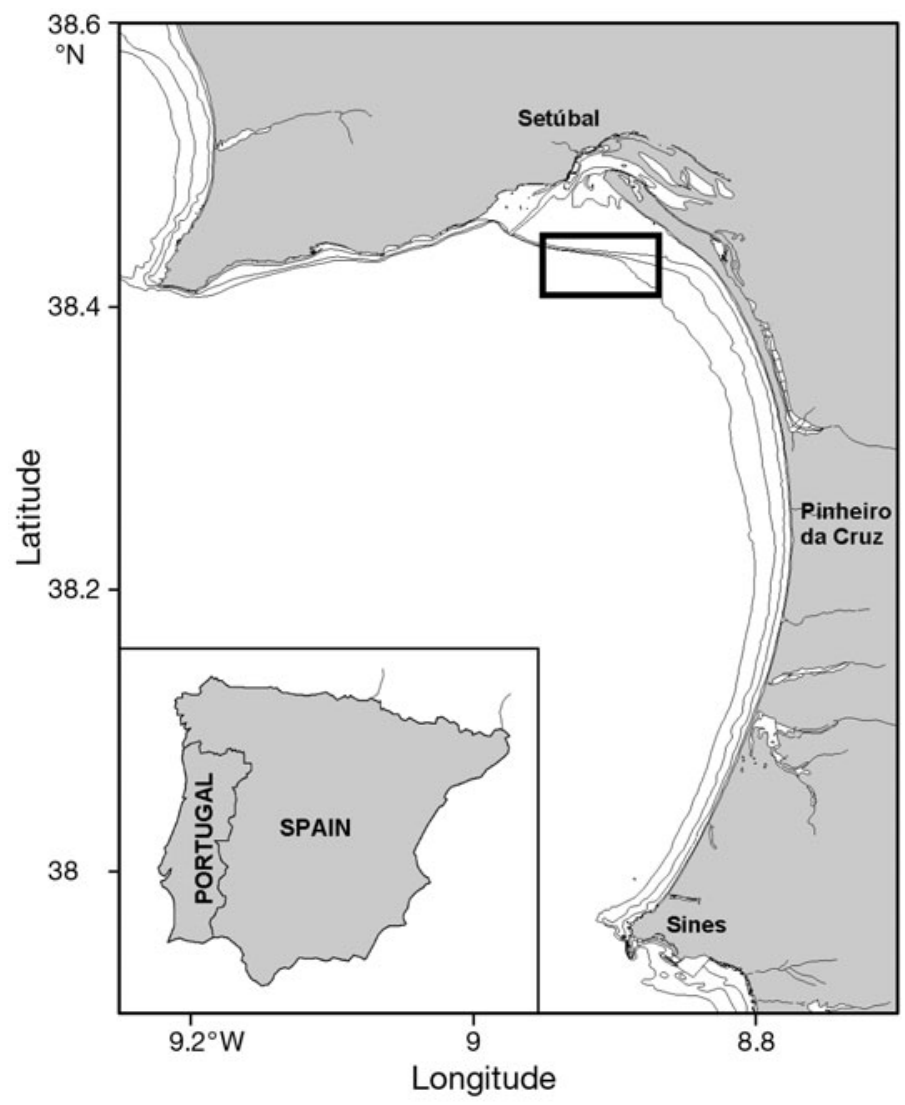

Fig. 1. Map showing the location of the Callista chione bed studied. Latitude and longitude scales are represented in centesimal degrees 

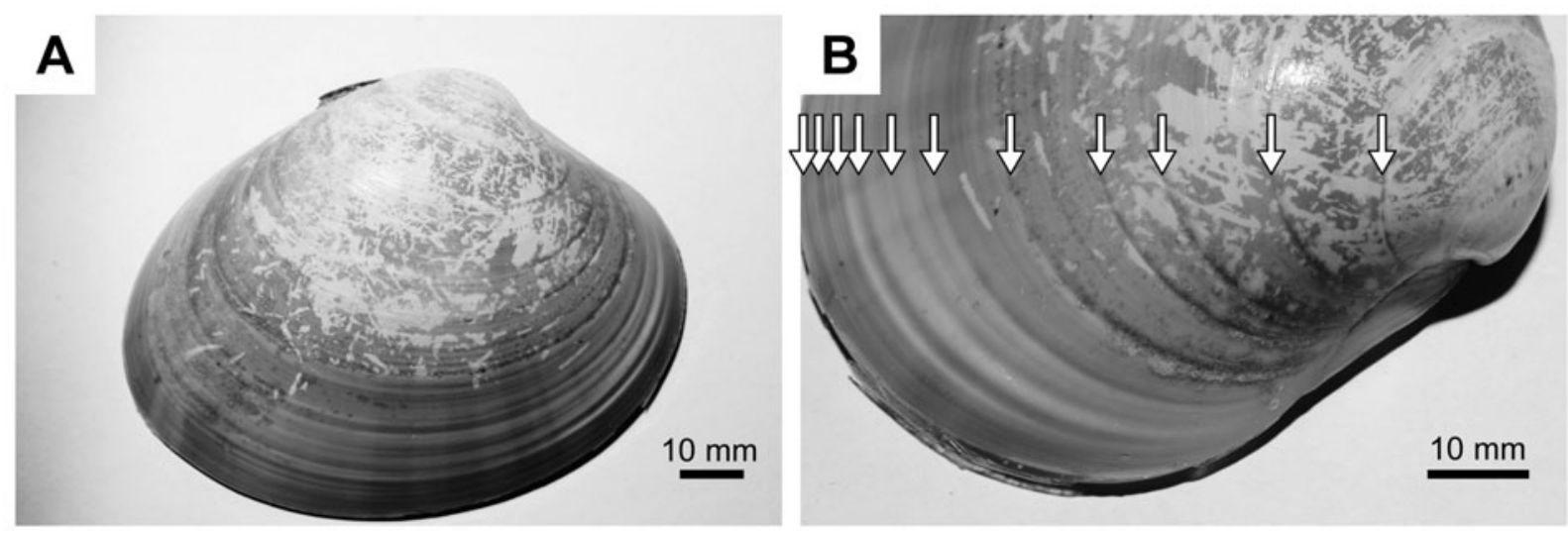

Fig. 2. Callista chione. (A) Shell and (B) surface growth rings (arrows) visible on the shell

sition pattern of growth lines was used to identify the position of each growth ring. For each growth ring, the distance between the umbo and the ring was marked and measured (to the nearest $0.01 \mathrm{~mm}$ ). Since these measurements are relative to shell height, data were converted into shell length using the following allometric relationships ( $\mathrm{n}=174$ and $\mathrm{r}=0.992$, where $H$ is shell height and $L$ is shell length; Gaspar et al. 2002):

$$
\log H=-0.163+1.043 \log L
$$

Von Bertalanffy growth (VBG) functions were fitted separately to the age-length data obtained for the 2 methods described above (surface shell rings and internal growth patterns) using the NLIN procedure of Statistica Software (Release 5.1). This interactive curvefitting procedure employs a non-linear, least-squares regression (quasi-Newton method) and estimates the von Bertalanffy growth constant $(K)$, the asymptotic maximum length $\left(L_{\infty}\right)$ and the theoretical age at length zero $\left(t_{0}\right.$; von Bertalanffy 1938):

$$
L_{t}=L_{\infty}\left(1-\mathrm{e}^{-K\left(t-t_{0}\right)}\right)
$$

Since individual growth is a non-linear process, the comparison of growth among different organisms or taxa is very difficult due to the problem of correlation between $K$ and $L_{\infty}$. To overcome this problem, several growth performance indexes have been used, namely, the overall growth performance (OGP, $P$ ) and the phiprime index $\left(\phi^{\prime}\right.$, growth performance index) (Pauly 1979, Munro \& Pauly 1983). In the present study, the OGP was used to compare the growth parameters obtained in our work with those from literature on venerid bivalves, whereas $\phi^{\prime}$ was calculated and compared with values from the literature on Callista spp., using the following expressions:

$$
\begin{gathered}
P=\log \left(K \times L_{\infty}^{3}\right) \\
\phi^{\prime}=\log K+2 \log L_{\infty}
\end{gathered}
$$

\section{RESULTS}

Acetate peel replicas of Callista chione shell sections are shown in Fig. 3. It was possible to identify 3 layers (described by Taylor et al. 1973): an outer composite prismatic layer, a middle crossed lamellar layer, and an inner homogeneous/complex crossed layer (Fig. 3A). Observation of the prismatic layer revealed distinct growth patterns deposited parallel to the ventral edge of the shell (Fig. 3C). Although poorly defined, these growth lines were also visible in the inner layer (Fig. 3A) and in the hinge plate region (Fig. 3B). The growth bands appeared as narrow dark lines (slow shell growth) separated by wider transparent regions (rapid shell growth; Fig. 3D). In older individuals, at the ventral shell margin these growth bands are often associated with depressions in the shell (Fig. 3E). The gradual decrease in the growth increment zone was the key to distinguishing annual rings from false rings (caused by stress or shell damage). The former were characterized by the progressive narrowing of growth bands, whereas stress rings were characterized by a sudden disruption of the natural growth pattern. Both types of rings were usually associated with a cleft in the shell surface. Examples of clefts in the shell surface are also shown in Fig. 3; these correspond to shell deformations caused by sand inclusion (Fig. 3F to $3 \mathrm{H}$ ) and shell damage (Fig. 3I to 3K).

Examination of the acetate peels of shell sections revealed seasonal variation in the percentage of individuals with a growth ring at the ventral margin of their shells. Fig. 4 shows the monthly percentage of individuals with a growth ring at the shell margin and the seasonal variation in seawater temperature. This Callista chione population began depositing narrow growth increments at the beginning of autumn, coincident with decreasing seawater temperatures. In September and October, $71 \%$ of the shells examined showed a growth mark at or close to the shell margin, 

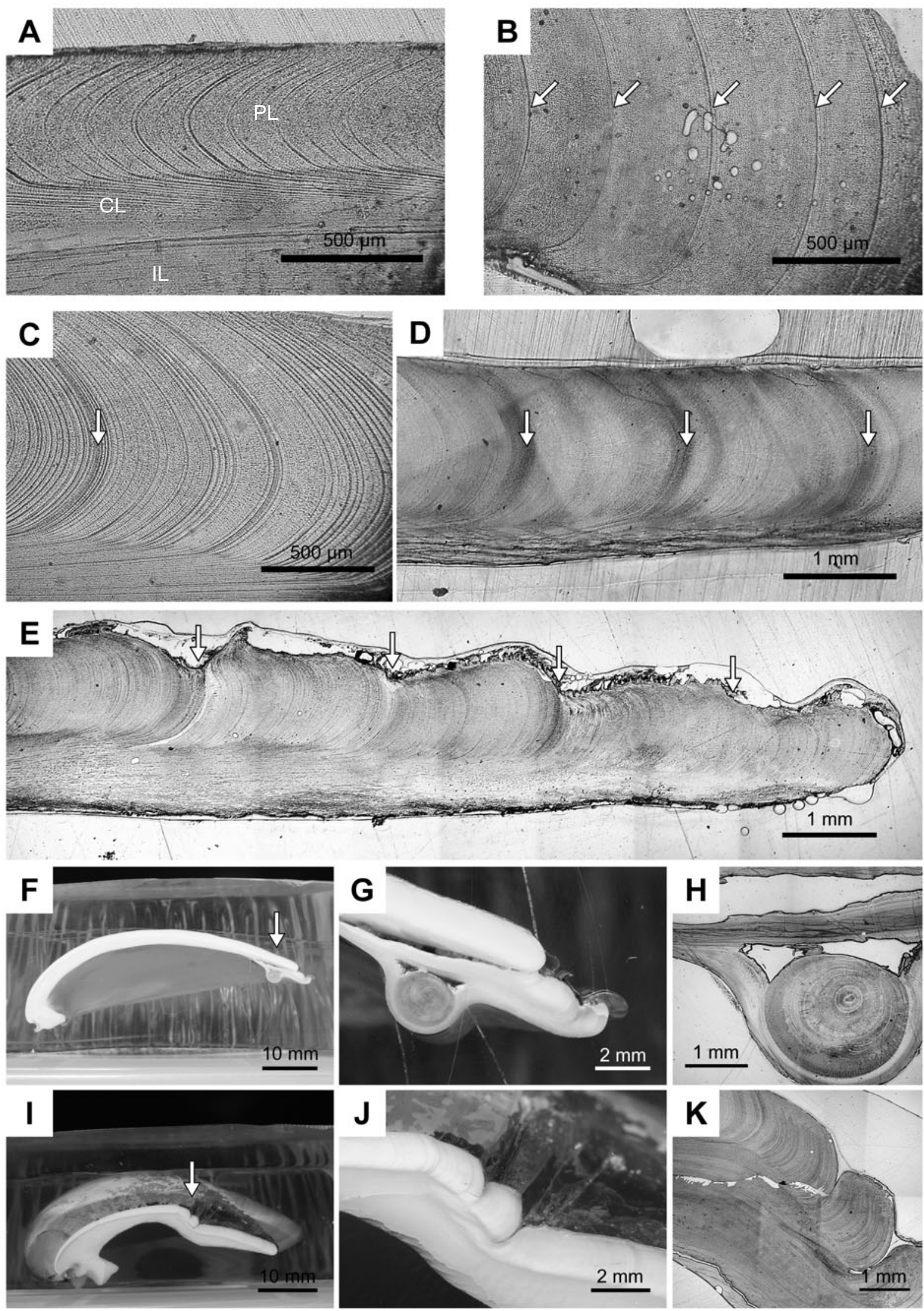
Fig. 3. Callista chione. Photomicrographs of acetate peel replicas of shell sections and blocks of resin-embedded shell: (A) microgrowth bands and shell layers (PL: outer prismatic layer, CL: middle crossed lamellar layer, IL: inner homogenous/complex crossed layer), (B) growth lines (arrows) in the hinge plate region, (C) growth patterns deposited forming an annual growth ring (arrow), (D) narrow dark lines (arrows) correspond to slow shell growth (internal growth rings), while the wider transparent regions represent rapid shell growth, (E) several growth rings with formation of distinct clefts in shell surface (arrows), (F) resin-embedded shell with a sand grain enclosed (arrow), (G) detail of sand grain enclosed in shell, $(\mathrm{H})$ acetate peel replica showing the microstructure of the sand grain enclosed in the shell, (I) resin-embedded shell with 2 evident clefts resulting from shell breakage (arrow), (J) detail of clefts in the shell and (K) acetate peel replica showing the breakage effect in shell microgrowth

reaching $86 \%$ of the shells in November, indicating that rapid shell growth took place in spring and summer, while the period of slow shell growth occurred during autumn and winter. This result also indicates that these growth rings are deposited once a year and therefore can be considered annual.

The mean length-at-age estimated using both the surface growth rings and internal shell growth patterns are presented in Table 1 . The maximum age determined using internal growth lines in shell sections was greater than that obtained through the surface growth rings (17 and $14 \mathrm{yr}$, respectively). Using the internal band method, the length \pm SD estimated for the first year was $18.09 \pm 1.9 \mathrm{~mm}$ SL. For $17 \mathrm{yr}$ olds, only 1 individual was sampled, with a size of $92.56 \mathrm{~mm}$ SL. The shell length estimated for the first year using the surface rings was $19.31 \pm 2.9 \mathrm{~mm}$ SL and for $14 \mathrm{yr}$ olds $84.06 \pm 9.2 \mathrm{~mm}$ SL. The variability in the estimation of mean length-at-age (represented by the respective standard deviations) was lower from growth lines in the cross-section than from external rings (Table 1).

Based on the age-length keys obtained by each method, the VBG equations that describe the growth of Callista chione were estimated as:

Surface rings:

$$
L_{t}=91.9\left(1-\mathrm{e}^{-0.18(t+0.22)}\right)
$$

Internal bands:

$$
L_{t}=98.1\left(1-\mathrm{e}^{-0.15(t+0.43)}\right)
$$

The VBG growth equation obtained using data from surface rings displayed a lower asymptotic size $\left(L_{\infty}=91.9 \mathrm{~mm} \mathrm{SL}\right)$ and a higher growth rate $\left(K=0.18 \mathrm{yr}^{-1}\right)$ than those obtained from internal growth bands $\left(L_{\infty}=98.1 \mathrm{~mm} \mathrm{SL} ; K=0.15 \mathrm{yr}^{-1}\right)$. The graphical representation of these equations shows that the growth curves estimated by both methods provided coincident growth rates until clams were 10 yr of age (Fig. 5).

Using these VBG equations and the size at first maturation previously estimated for this Callista chione population (50.81 mm SL; Moura et al. 2008), we estimated the respective age at first matu-

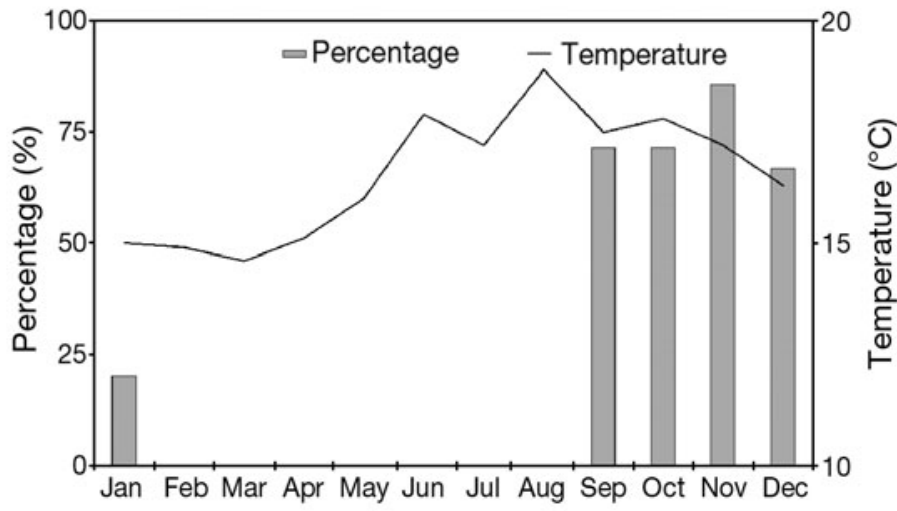

Fig. 4. Callista chione. Monthly frequency of individual clams with a growth ring at the shell margin and the variation in seawater temperature during the study period

rity. According to these calculations, the smooth clam off Arrábida reaches sexual maturation at between 4.25 (surface growth rings) and $4.44 \mathrm{yr}$ of age (internal growth bands). Concomitantly, C. chione attains minimum landing size (MLS $=60 \mathrm{~mm}$ SL) when they are between 5.69 and $5.88 \mathrm{yr}$ old, according to external rings and microgrowth bands, respectively.

Table 1. Callista chione. Mean length-at-age of individuals from Arrábida (southwestern Portugal), estimated from external growth rings and from

\begin{tabular}{|c|c|c|c|c|}
\hline \multirow{2}{*}{$\begin{array}{l}\text { Age } \\
\text { (yr) }\end{array}$} & \multicolumn{2}{|c|}{$\longrightarrow$ Surface rings -} & \multicolumn{2}{|c|}{ Internal bands } \\
\hline & $\begin{array}{c}\text { Mean SL (mm) } \\
\pm \text { SD }\end{array}$ & $\begin{array}{l}\text { SL range }(\mathrm{mm}) \\
(\min -\max )\end{array}$ & $\begin{array}{c}\text { Mean SL (mm) } \\
\pm \mathrm{SD}\end{array}$ & $\begin{array}{l}\text { SL range }(\mathrm{mm}) \\
(\min -\max )\end{array}$ \\
\hline 1 & $19.31 \pm 2.9$ & $16.17-24.43$ & $18.09 \pm 1.9$ & $15.46-20.94$ \\
\hline 2 & $29.95 \pm 5.3$ & $22.76-36.82$ & $29.75 \pm 2.5$ & $26.15-33.30$ \\
\hline 3 & $40.17 \pm 5.7$ & $31.77-48.09$ & $41.36 \pm 3.8$ & $35.74-45.67$ \\
\hline 4 & $49.32 \pm 4.6$ & $41.71-54.88$ & $49.02 \pm 3.3$ & $43.85-52.51$ \\
\hline 5 & $56.72 \pm 6.0$ & $49.10-63.82$ & $56.00 \pm 3.2$ & $51.06-60.58$ \\
\hline 6 & $62.86 \pm 6.2$ & $52.73-70.20$ & $62.23 \pm 4.4$ & $55.10-68.79$ \\
\hline 7 & $67.62 \pm 5.8$ & $58.95-74.53$ & $66.52 \pm 4.7$ & $60.18-74.18$ \\
\hline 8 & $72.26 \pm 6.0$ & $64.38-79.28$ & $70.86 \pm 4.3$ & $66.88-77.48$ \\
\hline 9 & $75.25 \pm 6.5$ & $65.72-82.28$ & $74.77 \pm 4.3$ & $70.50-81.80$ \\
\hline 10 & $77.36 \pm 6.8$ & $68.21-84.44$ & $76.96 \pm 4.3$ & $72.56-83.63$ \\
\hline 11 & $79.73 \pm 7.6$ & $69.75-88.00$ & $78.84 \pm 4.6$ & $73.30-84.73$ \\
\hline 12 & $81.50 \pm 8.1$ & $72.56-89.27$ & $82.61 \pm 3.6$ & $76.65-85.75$ \\
\hline 13 & $85.31 \pm 8.5$ & $75.46-90.54$ & $84.00 \pm 3.6$ & $77.88-86.53$ \\
\hline 14 & $84.06 \pm 9.2$ & $77.55-90.56$ & $85.90 \pm 3.7$ & $79.67-88.56$ \\
\hline 15 & - & - & $90.47 \pm 0.6$ & $90.05-90.89$ \\
\hline 16 & - & - & 91.52 & - \\
\hline 17 & - & - & 92.56 & - \\
\hline
\end{tabular}
growth bands in acetate peel replicas of shell sections. SL: shell length 


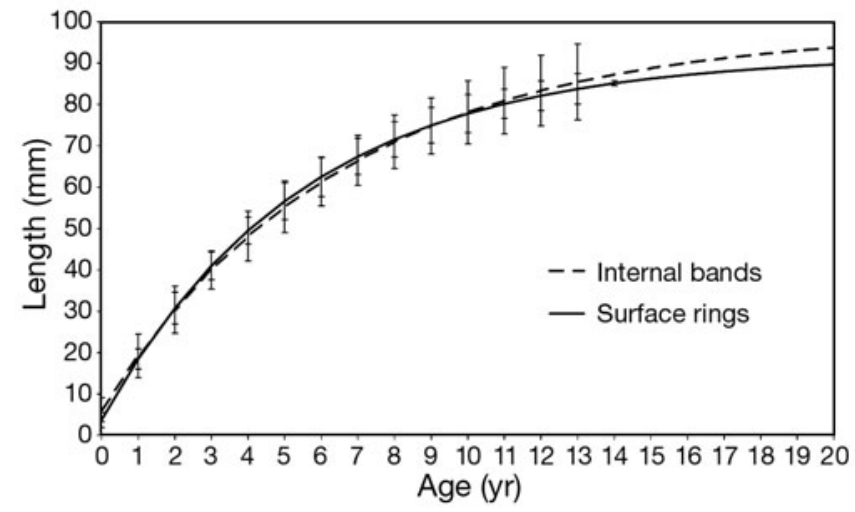

Fig. 5. Callista chione. von Bertalanffy growth curves determined from surface rings and from internal bands in acetate peel replicas of shell sections (error bars represent standard deviation of mean shell length)

OGP and $\phi^{\prime}$ values obtained in the present study using surface shell rings were $P=5.13$ and $\phi^{\prime}=3.17$, respectively, whilst when age was estimated using the microgrowth patterns in shell sections OGP was 5.15 and $\phi^{\prime}$ was 3.16.

\section{DISCUSSION}

In the present study it was possible to identify distinct growth patterns on the prismatic layer of the shells. The annual growth rings, corresponding to slow shell growth, appeared as narrow dark lines separated by wider transparent regions (rapid shell growth) and, in older individuals, recently deposited growth rings were often associated with a depression which corresponded to a cleft in the outer shell layer. Several shell deformations were also observed in the clams; most of them were probably caused by dredging (e.g. Robinson \& Richardson 1998, Ramsay et al. 2000, Gaspar et al. 2004b). However, factors other than fishing may also cause the formation of shell scars, namely predation (Richardson et al. 1980, Hughes \& Seed 1981), storms and other abnormal environmental conditions (Richardson et al. 1980, Checa 1993, Henderson \& Richardson 1994). The majority of shell deformations comprised the inclusion of sand grains or the formation of deep clefts. The diversity of shell deformations observed suggests that Callista chione has a high capacity for shell repair.

Rapid shell growth occurred in spring and summer, when wide microgrowth increments were deposited, whilst slow growth occurred during autumn and winter, with the deposition of narrow growth increments and the formation of an annual growth ring. The timing of growth in Callista chione appears to be influenced by factors related to seawater temperature. Some researchers suggest that growth increments in bivalves are directly or indirectly related to tem- perature (Gaspar et al. 2004a), while others indicate alternative physical and biological factors that also influence shell deposition (Rhoads \& Pannella 1970, Leontarakis \& Richardson 2005). In a recent study on the reproductive cycle of the smooth clam from the southwestern Portuguese coast (Moura et al. 2008), it was determined that this population has no resting period and that a new gametogenic cycle began in early November, immediately after several spawning episodes. During this period, the energetic reserves are probably directed towards the recovery of gonads, inducing a phase of slow growth in C. chione. A similar growth pattern was observed in a population of smooth clams from Greece (Thracian Sea; Leontarakis \& Richardson 2005). Other bivalve species from the Algarve coast (southern Portugal), namely Donax trunculus and Chamelea gallina, also showed the same seasonal growth pattern (Gaspar et al. 1999, 2004a).

The estimated growth curves obtained from surface growth rings and internal microgrowth patterns revealed that both methods provided similar estimates of growth rates until $10 \mathrm{yr}$ of age $(\approx 75 \mathrm{~mm}$ SL). Afterwards, the age of smooth clams was more accurately determined based on the internal growth bands in shell sections than directly from surface growth rings. This had already been expected, because the growth rate is slower in older specimens and, consequently, it becomes more difficult to distinguish and measure surface rings close to the edge of the shell. For this reason, the examination of surface rings (more rapid and economic) might be appropriate for estimating the growth rates on Callista chione specimens up to $75 \mathrm{~mm}$ SL or $10 \mathrm{yr}$ old, whereas the analysis of shell microstructure is highly recommended for estimating the growth rates of individuals $>75 \mathrm{~mm}$ SL. Similarly, Leontarakis \& Richardson (2005) reported that growth rings on smooth clams from Greece (Thracian Sea) were clearly visible on the shell surface and in acetate peel treatment of shell cross sections, although, in individuals $>10 \mathrm{yr}$ old, rings became relatively narrow and more closely spaced. In general, these results contradict the conclusions of another study carried out in Greece (Aegean Sea) by Metaxatos (2004), where the number of internal growth rings closely matched the number of external rings, therefore suggesting that surface annual growth rings could be used as an accurate age marker.

The growth curves estimated according to the 2 methods employed in the present study indicate that Callista chione grow relatively quickly during the first $5 \mathrm{yr}$ of life and then growth gradually slows. The minimum landing size stipulated for the smooth clam (60 $\mathrm{mm} \mathrm{SL}$ ) is reached when it is around $5.5 \mathrm{yr}$ old. The present results are in agreement with other studies on the age and growth of $C$. chione (Forster 1981, Keller et al. 2002, Metaxatos 2004, Leontarakis \& Richardson 
Table 2. Callista chione. Growth parameters for C. chione from distinct geographical areas, estimated using different age determination techniques. $L_{\infty}$ : asymptotic maximum length, SL: shell length, $K$ : von Bertalanffy growth constant. Methods were SR: surface rings, AP: acetate peels, MR: mark and recapture, IC: isotopic composition

\begin{tabular}{|c|c|c|c|c|c|}
\hline Study area & Method & $\begin{array}{c}L_{\infty} \\
(\mathrm{mm} \mathrm{SL})\end{array}$ & $K$ & $\underset{(\mathrm{yr})}{\operatorname{Maximum}}$ & Source \\
\hline \multicolumn{6}{|l|}{ Northeastern Atlantic } \\
\hline \multirow[t]{2}{*}{ Arrábida, Portugal } & SR & 91.9 & 0.18 & 14 & Present study \\
\hline & AP & 98.1 & 0.15 & 17 & Present study \\
\hline Whitsand Bay, UK & MR & 105.8 & 0.02 & $>40$ (predicted for $90 \mathrm{~mm} \mathrm{SL)}$ & Forster (1981) \\
\hline \multicolumn{6}{|l|}{ Mediterranean Sea } \\
\hline Gulf of Trieste, Italy (Adriatic Sea) & IC & & & 12 & Keller et al. (2002) \\
\hline Gulf of Euboikos, Greece (Aegean Sea) & $\mathrm{SR}, \mathrm{AP}$ & 93 & 0.24 & 17 & Metaxatos (2004) \\
\hline \multirow{2}{*}{ Thassos Island, Greece (Thracian Sea) } & $\mathrm{SR}, \mathrm{AP}$ & 62.7 & 0.24 & 12 & Leontarakis \& \\
\hline & $\mathrm{SR}, \mathrm{AP}$ & 57.8 & 0.26 & 16 & Richardson (2005) \\
\hline
\end{tabular}

2005; Table 2). Despite not having estimated growth parameters, Keller et al. (2002), like the other researchers, described $C$. chione as a species with rapid growth during the first years and with quite slow growth in the latter years of life.

The asymptotic sizes $\left(L_{\infty}=91.9\right.$ and $98.1 \mathrm{~mm} \mathrm{SL}$, for surface rings and internal growth lines, respectively) estimated in the present study are similar to the results obtained for the population from the Aegean Sea (Metaxatos 2004). In our study, Callista chione displayed slower growth rates $(K=0.18$ and 0.15 , external rings and internal growth lines, respectively) than did the populations studied in Greece, with $K=0.24$ in the Aegean Sea (Metaxatos 2004) and $K=0.24$ or 0.26 in the Thracian Sea (Leontarakis \& Richardson 2005). The slower growth rate in the present study had been expected, because these smooth clams were collected in Atlantic waters, whereas the others were sampled in warmer Mediterranean waters. The lifespans estimated in the present work were 14 and $17 \mathrm{yr}$ (for sur- face rings and internal growth lines, respectively), which were relatively similar to the maximum ages obtained by Keller et al. (2002), Metaxatos (2004) and Leontarakis \& Richardson (2005). In contrast, the Atlantic population of $C$. chione studied in the UK by Forster (1981) showed very dissimilar results, with a larger asymptotic size, a much slower growth rate and a much higher predicted maximum age. These discrepancies could possibly be a consequence of the mark-and-recapture method used by Forster (1981) and its inherent practical problems. Besides, this author only used individuals with a SL $>73 \mathrm{~mm}$ to estimate growth rates. Therefore, his results are probably age-biased since $C$. chione growths faster in the first years of its life.

In the present work, the OGP determined from both the microgrowth patterns in shell sections and the surface rings lie within the range of values determined by other authors for Callista spp. Indeed, the OGP for most Callista spp. has been found to fall within the

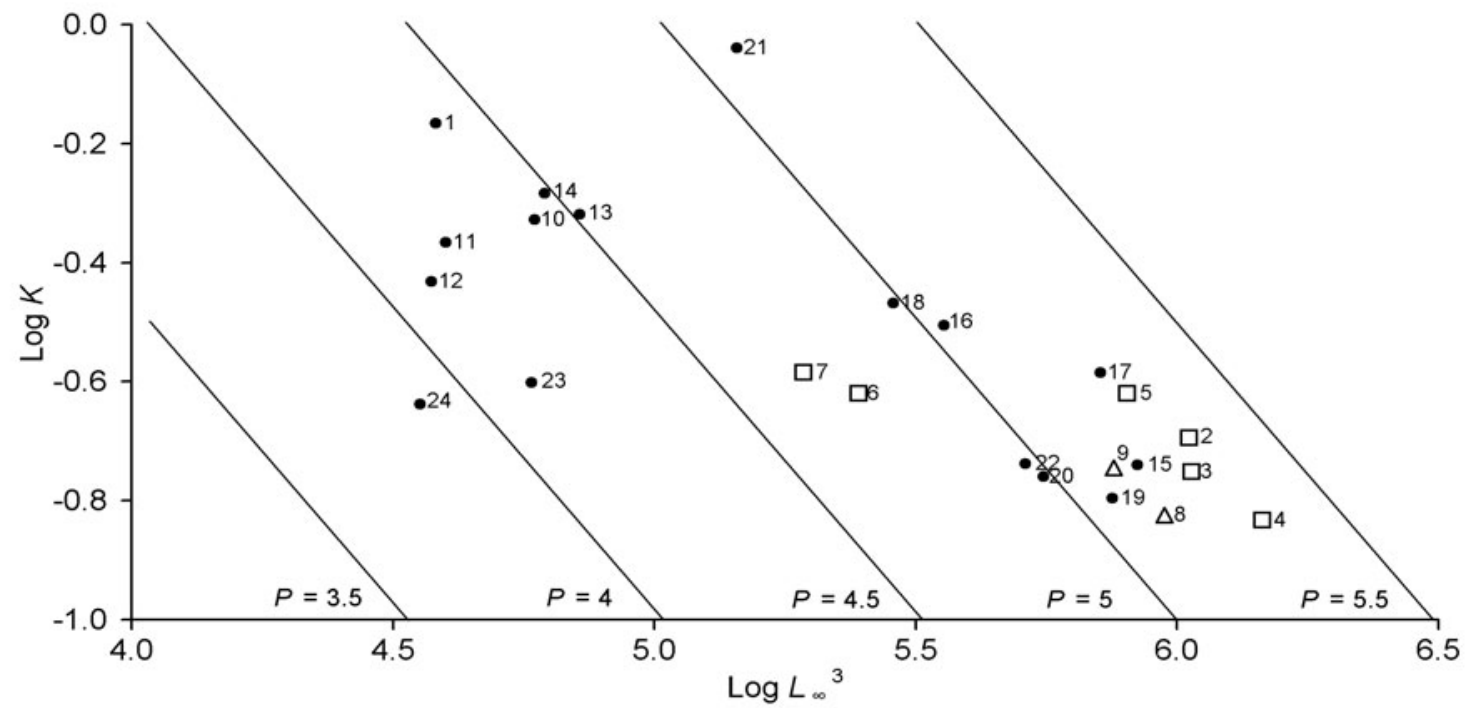

Fig. 6. Auximetric grid comparing overall growth performance (OGP, $P$ ) in venerid bivalves. Diagonal lines indicate equal values of OGP. Numbers refer to the reference numbers in Table 3 ( $\triangle$ : present study; $\square$ : Callista spp.; $\bullet$ : other Veneridae) 
Table 3. Values of von Bertalanffy growth constant $(K)$ and growth performance indices $\left(P, \phi^{\prime}\right)$ for various venerid bivalve species. Age determination method: LF: length-frequency, SR: surface rings, CS: cross sections, TS: thin sections, AP: acetate peels, MR: mark and recapture

\begin{tabular}{|c|c|c|c|c|c|c|c|c|}
\hline $\begin{array}{l}\text { Taxon and } \\
\text { Ref. no. }\end{array}$ & $K$ & $L_{\infty}(\mathrm{mm} \mathrm{SL})$ & $P$ & $\phi^{\prime}$ & $\begin{array}{l}\text { Latitude } \\
\qquad\left({ }^{\circ} \mathrm{N}\right)\end{array}$ & Method & Study area & Source \\
\hline \multicolumn{9}{|c|}{ Anomalocardia brasiliana } \\
\hline 1 & 0.682 & 33.67 & 4.42 & & & $\mathrm{LF}$ & Guadeloupe, Carribean Sea & Monti et al. (1991) \\
\hline \multicolumn{9}{|c|}{ Callista brevisiphonata } \\
\hline 2 & 0.202 & 101.80 & 5.33 & 3.32 & 42.51 & $\mathrm{SR}, \mathrm{CS}$ & $\begin{array}{l}\text { Unkovskii Island, Peter the Great Bay, } \\
\text { Sea of Japan }\end{array}$ & Selin \& Selina (1988) \\
\hline 3 & 0.177 & 102.20 & 5.28 & 3.27 & 42.48 & $\mathrm{SR}, \mathrm{CS}$ & $\begin{array}{l}\text { Putyatin Island, Peter the Great Bay, } \\
\text { Sea of Japan }\end{array}$ & Selin \& Selina (1988) \\
\hline 4 & 0.147 & 113.40 & 5.33 & 3.28 & 42.53 & $\mathrm{SR}, \mathrm{CS}$ & $\begin{array}{l}\text { Tikhaya zavod inlet, Peter the Great Bay, } \\
\text { Sea of Japan }\end{array}$ & Selin \& Selina (1988) \\
\hline \multicolumn{9}{|c|}{ Callista chione } \\
\hline 5 & 0.240 & 93.00 & 5.29 & 3.32 & 38.50 & SR, TS & $\begin{array}{l}\text { Gulf of Euboikos, Aegean Sea, } \\
\text { Mediterranean }\end{array}$ & Metaxatos (2004) \\
\hline 6 & 0.240 & 62.70 & 4.77 & 2.97 & 40.40 & $\mathrm{SR}, \mathrm{AP}$ & Thracian Sea, Mediterranean & Leontarakis \& Richardson (2005) \\
\hline 7 & 0.260 & 57.80 & 4.70 & 2.94 & 40.40 & $\mathrm{SR}, \mathrm{AP}$ & Thracian Sea, Mediterranean & Leontarakis \& Richardson (2005) \\
\hline 8 & 0.150 & 98.10 & 5.15 & 3.16 & 38.20 & $\mathrm{AP}$ & Arrábida, NE Atlantic, Portugal & Present study \\
\hline 9 & 0.180 & 91.10 & 5.13 & 3.17 & 38.20 & SR & Arrábida, NE Atlantic, Portugal & Present study \\
\hline \multicolumn{9}{|c|}{ Chamelea gallina } \\
\hline 10 & 0.470 & 38.95 & 4.44 & & & $\mathrm{AP}$ & Algarve, S Portugal & Gaspar et al. (2004a) \\
\hline 11 & 0.430 & 34.17 & 4.23 & & & SR & N Marmara Sea, Turkey & Deval \& Oray (1998) \\
\hline 12 & 0.370 & 33.46 & 4.14 & & & $\mathrm{AP}$ & N Marmara Sea, Turkey & Deval (2001) \\
\hline 13 & 0.480 & 41.60 & 4.54 & & & TS & W Adriatic, Ancona, Italy & Arneri et al. (1995) \\
\hline 14 & 0.520 & 39.50 & 4.51 & & & TS & W Adriatic, Neretva Estuary, Croatia & Arneri et al. (1997) \\
\hline \multicolumn{9}{|c|}{ Mercenaria mercenaria } \\
\hline 15 & 0.182 & 94.31 & 5.18 & & & SR & English Channel, Southampton, UK & Hibbert (1977) \\
\hline 16 & 0.312 & 71.04 & 5.05 & & & $\mathrm{AP}$ & Atlantic, Georgia, USA & Walker \& Tenore (1984) \\
\hline 17 & 0.260 & 89.40 & 5.27 & & & $\mathrm{AP}$ & Atlantic, Georgia, USA & Walker \& Tenore (1984) \\
\hline 18 & 0.340 & 65.90 & 4.99 & & & $\mathrm{AP}$ & Atlantic, Georgia, USA & Walker \& Tenore (1984) \\
\hline 19 & 0.160 & 90.90 & 5.08 & & & $\mathrm{AP}, \mathrm{CS}$ & Narragansett Bay, Rhode Island, USA & Jones et al. (1989) \\
\hline \multicolumn{9}{|c|}{ Protothaca thaca } \\
\hline 20 & 0.174 & 82.20 & 4.99 & & & $\mathrm{SR}, \mathrm{MR}$ & Bay of Dichato, Chile & Urban \& Campos (1994) \\
\hline \multicolumn{9}{|c|}{ Tapes philippinarum } \\
\hline 21 & 0.913 & 52.40 & 5.12 & & & $\mathrm{LF}$ & Kaneohe Bay, Pacific, Hawaii & Yap (1977) \\
\hline \multicolumn{9}{|c|}{ Venus antiqua } \\
\hline 22 & 0.183 & 80.00 & 4.97 & & & MR & Chiloé, Pacific, Chile & Clasing et al. (1994) \\
\hline \multicolumn{9}{|c|}{ Venus striatula } \\
\hline 23 & 0.250 & 38.75 & 4.16 & & & SR & Bristol Channel, UK & Warwick et al. (1978) \\
\hline 24 & 0.230 & 32.90 & 3.91 & & & SR & Millport, Scotland & Ursin (1963) \\
\hline
\end{tabular}

range of 5 to 5.5 (Fig. 6, Table 3). Moreover, the OGP values indicate that species of the genus Callista have a higher growth performance (average OGP: $P=$ 5.12) than other venerid bivalves (average OGP: $P=4.79$; Fig. 6, Table 3 ). The $\phi^{\prime}$ values obtained in the present study according to both age determination methods are consistent with those previously calculated for other Callista spp. populations (Fig. 7, Table 3). This result indicates that the growth parameters $K$ and $L_{\infty}$ estimated in the present work are

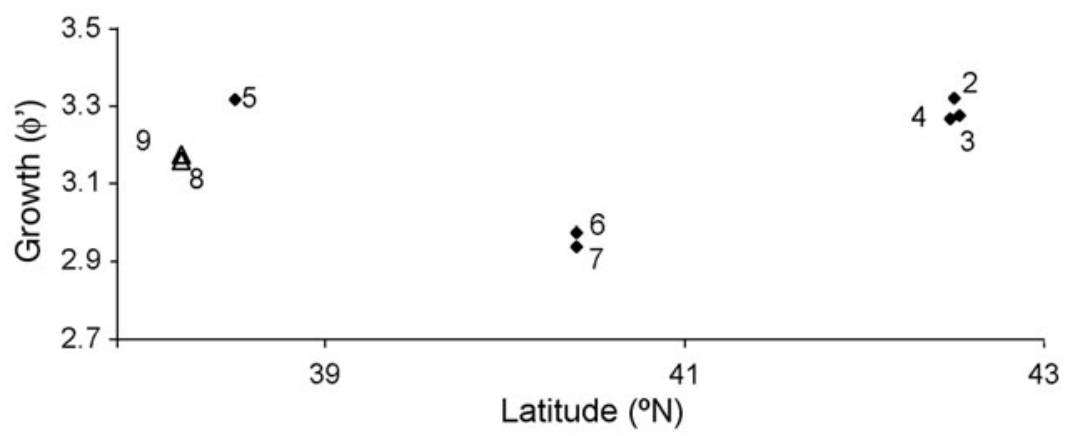

Fig. 7. Callista spp. Growth performance index values $\left(\phi^{\prime}\right)$ along a latitudinal gradient. Numbers refer to the reference numbers in Table 3 ( $\Delta$ : present study) 
an accurate representation of the considered population, since it has been suggested that $\phi^{\prime}$ values are similar for the same species and genera (Munro \& Pauly 1983, Brey 1999, Bellido et al. 2000). Yet, growth performance seems to present a positive correlation with latitude for the Callista spp. populations shown in Fig. 7. This may be related to differences in seawater temperature and food supply.

Knowledge on the age and growth of bivalve species is a fundamental requirement for studies of population dynamics and, consequently, for the successful management of a fishery. Taking into consideration the size at first maturity (50.81 mm SL) previously estimated by Moura et al. (2008), Callista chione needs $>4$ yr to reach sexual maturation. Unfortunately, comparisons with other smooth clam populations were impossible, since no further information is available on this subject.

Acknowledgements. The authors thank the technical staff of the IPIMAR's Setúbal Delegation, namely Maria da Luz and António Laranjo, for their collaboration in collecting the samples. We are particularly grateful to Dr. Thomas Brey, who let us use his compilation of data on invertebrate growth and provided several bibliography tips. Thanks are also due to Dr. Nikolay Selin, who provided us with some valuable literature sources. We thank Dr. João Cúrdia for taking the microphotographs of the acetate peel replicas of shell cross sections. This study was carried out within the framework of the project 'Observatório Científico de las Pesquerias Artesanales' (OCIPESCA) under the INTERREG IIIB Programme-Atlantic Area, co-financed by the European Union (ERDF) and the Portuguese government.

\section{LITERATURE CITED}

Arneri E, Gianneti G, Polenta R, Antolini B (1995) Age and growth of Chamelea gallina (Bivalvia: Veneridae) in the Central Adriatic Sea obtained by thin sections. Rapp Comm Int Mer Medit 34:1-17

Arneri E, Froglia C, Polenta R, Antolini B (1997) Growth of Chamelea gallina (Bivalvia: Veneridae) in the eastern Adriatic (Neretva River Estuary). Tisuću Godina Prvoga Spomena Ribarstva u Hrvata 597:669-676

Bellido JM, Pierce GJ, Romero JL, Millán M (2000) Use of frequency analysis methods to estimate growth of anchovy (Engraulis encrasicolus L., 1758) in the Gulf of Cadiz (SW Spain). Fish Res 48:107-115

> Brey T (1999) Growth performance and mortality in aquatic macrobenthic invertebrates. Adv Mar Biol 35:153-223

Cerrato RM (1980) Demographic analysis of bivalve populations. In: Rhoads DC, Lutz RA (eds) Skeletal growth of aquatic organisms. Plenum Press, New York, p 417-468

Checa A (1993) Non-predatory shell damage in recent deependobenthic bivalves from Spain. Palaeogeogr Palaeoclimatol Palaeoecol 100:309-331

Clasing E, Brey T, Stead R, Navarro J, Asencio G (1994) Population dynamics of Venus antiqua (Bivalvia: Veneracea) in the Bahia de Yaldad, Isla de Chiloé, southern Chile. J Exp Mar Biol Ecol 177:171-186

Deval MC (2001) Shell growth and biometry of the striped venus Chamelea gallina (L.) in the Marmara Sea, Turkey. J Shellfish Res 20:155-159

Deval MC, Oray IK (1998) The annual shell increments of Bivalvia Chamelea gallina L., 1758 in the northern Sea of Marmara. Oebalia 24:93-109

Forster CR (1981) The age and growth of Callista chione. J Mar Biol Assoc UK 61:881-883

Gaspar MB, Ferreira R, Monteiro CC (1999) Growth and reproductive cycle of Donax trunculus L. (Mollusca: Bivalvia) off Faro, southern Portugal. Fish Res 41:309-316

Gaspar MB, Dias MD, Campos A, Monteiro CC, Santos MN, Chícharo A, Chícharo L (2001) The influence of dredge design on the catch of Callista chione (Linnaeus, 1758). Hydrobiologia 465:153-167

Gaspar MB, Santos MN, Vasconcelos P, Monteiro CC (2002) Shell morphometric relationships of the most common bivalves species (Mollusca: Bivalvia) of the Algarve coast (southern Portugal). Hydrobiologia 477:73-80

Gaspar MB, Pereira AM, Vasconcelos P, Monteiro CC (2004a) Age and growth of Chamelea gallina from the Algarve coast (southern Portugal): influence of seawater temperature and gametogenic cycle on growth rate. J Molluscan Stud 70:371-377

Gaspar MB, Vasconcelos P, Morgado-André C, MorgadoAndré A, Dias MD, Monteiro CC (2004b) Improvement of clam dredge design to reduce damage on the catches, based on shell strength experiments. In: Abstract volume of the 4th World Fisheries Congress, 2-6 May 2004, Vancouver, BC, p 234-235

> Hall CA Jr, Dollase WA, Corbató CE (1974) Shell growth in Tivela stultorum (Mawe, 1823) and Callista chione (Linnaeus, 1758) (Bivalvia): latitudinal differences, and diminution with age. Palaeogeogr Palaeoclimatol Palaeoecol 15:33-61

Henderson SM, Richardson CA (1994) A comparison of the age, growth-rate and burrowing behaviour of the razor clams Ensis siliqua and E. ensis. J Mar Biol Assoc UK 74: 939-954

> Hibbert CJ (1977) Growth and survivorship in a tidal-flat population of the bivalve Mercenaria mercenaria from Southampton water. Mar Biol 44:71-76

Hughes RN, Seed R (1981) Size selection of mussels by the blue crab Callinectes sapidus: Energy maximizer or time minimizer? Mar Ecol Prog Ser 6:83-89

Jones DS, Arthur MA, Allard DJ (1989) Sclerochronological records of temperature and growth from shells of Mercenaria mercenaria from Narragansett Bay, Rhode Island. Mar Biol 102:225-234

Katsanevakis S (2007) Growth and mortality rates of the fan mussel Pinna nobilis in Lake Vouliagmeni (Korinthiakos Gulf, Greece): a generalized additive modelling approach. Mar Biol 152:1319-1331

Keller N, Del Piero D, Longinelli A (2002) Isotopic composition, growth rates and biological behaviour of Chamelea gallina and Callista chione from the Gulf of Trieste (Italy). Mar Biol 140:9-15

> Laudien L, Brey T, Arntz WE (2003) Population structure, growth and production of the surf clam Donax serra (Bivalvia, Donacidae) on two Namibian sandy beaches. Estuar Coast Shelf Sci 58:105-115

> Leontarakis PK, Richardson CA (2005) Growth of the smooth clam, Callista chione (Linnaeus, 1758) (Bivalvia: Veneridae) from the Thracian Sea, northeastern Mediterranean. J Molluscan Stud 71:189-198

Lutz RA (1976) Annual growth patterns in the inner shell layer of Mytilus edulis L. J Mar Biol Assoc UK 56:723-731 Metaxatos A (2004) Population dynamics of the venerid 
bivalve Callista chione (L.) in a coastal area of the eastern Mediterranean. J Sea Res 52:293-305

Monti D, Frenkiel L, Moueza M (1991) Demography and growth of Anomalocardia brasiliana (Gmelin) (Bivalvia: Veneridae) in a mangrove, in Guadeloupe (French West Indies). J Molluscan Stud 57:249-257

Morsan EM, Orensanz JML (2004) Age structure and growth in an unusual population of purple clams, Amiantis purpuratus (Lamarck, 1818) (Bivalvia; Veneridae), from Argentine Patagonia. J Shellfish Res 23:73-80

Moura P, Gaspar MB, Monteiro CC (2008) Gametogenic cycle of the smooth clam Callista chione on the south-western coast of Portugal. J Mar Biol Assoc UK 88:161-167

Munro JL, Pauly D (1983) A simple method for comparing the growth of fishes and invertebrates. Fishbyte 1:5-6

Pannella G, MacClintock C (1968) Biological and environmental rhythms reflected in molluscan shell growth. J Paleontol 23:577-594

Pauly D (1979) Gill size and temperature as governing factors in fish growth: a generalization of von Bertalanffy's growth formula. Ber Inst Meereskd Christian-Albrechts Univ Kiel 63(15)1-156

Peharda M, Richardson CA, Mladineo I, Šestanović S, Popović Z, Bolotin J, Vrgoć N (2007) Age, growth and population structure of Modiolus barbatus from the Adriatic. Mar Biol 151:629-638

Ramsay K, Kaiser MJ, Richardson CA, Veale LO, Brand AR (2000) Can shell scars on dog cockles (Glycymeris glycymeris L.) be used as an indicator of fishing disturbance? J Sea Res 43:167-176

Rhoads DC, Pannella G (1970) The use of molluscan growth patterns in ecology and paleoecology. Lethaia 3:143-161

Richardson CA (1989) An analysis of the microgrowth bands in the shell of the common mussel Mytilus edulis. J Mar Biol Assoc UK 69:477-491

Richardson CA (2001) Molluscs as archives of environmental change. Oceanogr Mar Biol Annu Rev 39:103-164

Richardson CA, Crisp DJ, Runham NW (1980) Factors influencing shell growth in Cerastoderma edule. Proc R Soc

Editorial responsibility: Otto Kinne,

Oldendorf/Luhe, Germany
Lond B Biol Sci 210:513-531

Richardson CA, Seed R, Naylor E (1990) Use of internal growth bands for measuring individual and population growth rates in Mytilus edulis from offshore production platforms. Mar Ecol Prog Ser 66:259-265

> Robinson RF, Richardson CA (1998) The direct and indirect effects of suction dredging on a razor clam (Ensis arcuatus) population. ICES J Mar Sci 55:970-977

Seed R (1976) Ecology. In: Bayne BL (ed) Marine mussels: their ecology and physiology. Cambridge University Press, Cambridge, p 13-65

Selin NI, Selina MS (1988) Production characteristics of the bivalve mollusc Callista brevisiphonata in Peter the Great Bay, Sea of Japan. Sov J Mar Biol 14:219-223

Taylor JD, Kennedy WJ, Hall A (1973) The shell structure and mineralogy of the Bivalvia. II. Lucinacea-Clavagellacea conclusions. Bull Br Mus (Nat Hist) Zool 22:255-294

> Urban HJ (2000) Culture potential of the pearl oyster (Pinctada imbricata) from the Caribbean. I. Gametogenic activity, growth, mortality and production of a natural population. Aquaculture 189:361-373

> Urban HJ, Campos B (1994) Population dynamics of the bivalves Gari solida, Semele solida and Protothaca thaca from a small bay in Chile at $36^{\circ} \mathrm{S}$. Mar Ecol Prog Ser 115: 93-102

Ursin E (1963) On the incorporation of the temperature in the von Bertalanffy growth equation. Medd Dan Fisk Havunders NY Ser 4:1-16

von Bertalanffy L (1938) A quantitative theory of organic growth. Hum Biol 10:181-213

Walker RL, Tenore KR (1984) The distribution and production of the hard clam, Mercenaria mercenaria, in Wassaw Sound, Georgia. Estuaries 7:19-27

Warwick RM, George CL, Davies JR (1978) Annual macrofauna production in a Venus community. Estuar Coast Mar Sci 7:215-241

Yap WG (1977) Population biology of the Japanese little-neck clam, Tapes philippinarium, in Kaneohe Bay, Oahu, Hawaiian Islands. Pac Sci 31:223-244

Submitted: September 11, 2008; Accepted: December 4, 2008 Proofs received from author(s): February 20, 2009 